\title{
Chemotactic activity of Helicobacter pylori sonicate for human polymorphonuclear leucocytes and monocytes
}

\author{
H Nielsen, L P Andersen
}

\begin{abstract}
The immunopathology of Helicobacter pylori associated active chronic gastritis, which is characterised by predominance of polymorphonuclear leucocyte infiltration, is largely unknown. To evaluate the role of bacterial components as inflammatory mediators ultracentrifuged sonicated preparations were made of clinical isolates of Helicobacter pylori. The crude sonicates were shown to exhibit chemotactic activity for human polymorphonuclear leucocytes and blood monocytes in a concentration dependent fashion. The potency was comparable with previously described bacterial derived cytotaxins. The cytotaxin(s) was non-dialysable and completely destroyed by proteinase. Heat treatment did not decrease the chemotactic activity, but in sonicate subjected to $100^{\circ} \mathrm{C}$ for 15 minutes all activity disappeared after dialysis suggesting the breakdown of a larger protein to small fragments that are still biological active. By ammonium sulphate precipitation at increasing concentrations the cytotaxin(s) was selectively found in $10 \%$ ammonium sulphate saturation, and by further molecular gel separation the chemotactic activity was found in the molecular size range from 25 to $35 \mathrm{kDa}$. The demonstration of a polymorphonuclear leucocyte and monocyte cytotaxin from Helicobacter pylori sonicate may help in understanding the mucosal immune response in gastric inflammatory diseases.
\end{abstract}

The close association between gastric inflammatory disease and the Gram negative bacterium Helicobacter pylori (formerly Campylobacter pylori) ${ }^{1}$ is now well established..$^{2-4} \mathrm{H}$ pylori has a particular tropism for the gastric epithelium, because it specifically colonises the surface mucous layer of the antral mucosa and in cases of gastric metaplasia also the duodenal mucosa ${ }^{5}$ and it may even penetrate the epithelium and its basement membrane. ${ }^{6}$ There appears now to be little doubt that the bacterium is causally related to gastric inflammatory diseases and this is supported by epidemiological data ${ }^{7}$ as well as the presence of gastritis after ingestion of viable organisms. ${ }^{8}$

Patients with $H$ pylori gastritis develop a local and systemic humoral response with IgG and $\operatorname{IgA}$ antibodies, but despite this immune response the disease persists. ${ }^{10}$ On histological examination $H$ pylori is localised in areas of inflammation dominated by infiltration with polymorphonuclear leucocytes, but also macrophages and T-lymphocytes are found in increased numbers. $H$ pylori is only occasionally cultured from gastric specimens without active chronic inflammation. ${ }^{112}$ After pharmacological elimination of $H$ pylori a marked improvement in histology have been reported, ${ }^{1314}$ which contrasts the persistence of active chronic gastritis with polymorphonuclear leucocytes in patients given placebo.

The mechanisms involved in regulating the inflammatory response to $H$ pylori infection of the gastric mucosa is unknown. The close histological association of $H$ pylori and polymorphonuclear leucocytes suggests, however, recruitment by inflammatory mediators. Binding of specific IgG to the bacterium increases complement dependent phagocytosis by polymorphonuclear leucocytes, ${ }^{15} 16$ and incubation of $H$ pylori in human serum generates the chemotactic complement split products $\mathrm{C} 3 \mathrm{a}$ and $\mathrm{C} 5 \mathrm{a} .{ }^{17}$ The role of bacterial factors as inflammatory mediators have not been studied. We report here the identification and partial characterisation of a bacterial protein from $H$ pylori sonicate with chemoattractant activity for human polymorphonuclear leucocytes and monocytes.

\section{Methods}

\section{BACTERIAL STRAINS}

Bacteria recovered from gastric biopsy specimens were identified as $H$ pylori based on colony morphology after growth under microaerophilic conditions at $37^{\circ} \mathrm{C}$ for three to six days, Gram's stain, and the production of urease, catalase, and oxidase. The test strain of $H$ pylori used for most of the studies was a clinical isolate $(\mathrm{CH}-20249)$ from the antral gastric biopsy of a 53 year old man with duodenal ulcer. Confirmatory studies were carried out with two additional clinical isolates (GE-40001 and GE-40003) obtained from the antral part of the stomach from two children with abdominal pain and normal endoscopic findings. Bacteria used in these studies was subcultured from five to 15 times subsequent to primary isolation before large scale sonicate preparations were performed.

\section{PREPARATION OF HELICOBACTER PYLOR} SONICATE

Pure cultures of $H$ pylori were grown on chocolate agar plates under microaerophilic conditions. After 24 to 48 hours of incubation at $37^{\circ} \mathrm{C}$, the non-contaminated plates were harvested in sterile distilled water. Bacteria were washed twice in distilled water and disintegrated 
by sonication three times for 45 seconds at 20000 $\mathrm{Hz}$, using a Rapidis $350,19-\mathrm{mm}$ probe with a 9.5-mm tip, and centrifuged at $48000 \times g$ for one hour at $4^{\circ} \mathrm{C}$. In some experiments the bacteria were sonicated five times for 45 seconds, and in others the crude sonic extract was tested before centrifugation. The supernatant was filtered through a $0.22 \mu \mathrm{m}$ Millipore filter. Sterility of the sonicate was controlled on $5 \%$ blood agar plates incubated microaerophilic and aerobic at $37^{\circ} \mathrm{C}$. The antigen concentration was measured by refractometry using human immunoglobulin as a standard. The sonicate was stored in small aliquots at $-20^{\circ} \mathrm{C}$.

\section{TREATMENT OF H PYLORI SONICATE}

To further characterise the active component(s) of $H$ pylori sonicate the following were performed. (i) Heat treatment for 15 and 60 minutes at $56^{\circ} \mathrm{C}, 70^{\circ} \mathrm{C}$, or $100^{\circ} \mathrm{C}$ by immersion a sample of sonicate in a water bath; (ii) dialysis of untreated as well as heat treated sonicate overnight against phosphate buffered saline with a cut off at 6-8 $\mathrm{kDa}$; (iii) ammonium sulphate precipitation with increasing concentrations: $10,15,25,40,50,75$, 85 , and $95 \%$; (iv) molecular gel chromatography on a Sephadex G-50 column; (vi) treatment with $2 \mathrm{mg} / \mathrm{ml}$ pronase (Sigma) for one hour with heat destroyed pronase $\left(100^{\circ} \mathrm{C}\right.$ for 10 minutes $)$ as a control.

ISOLATION OF POLYMORPHONUCLEAR

LEUCOCYTES AND MONOCYTES

Peripheral venous blood of healthy donors was separated on Dextran sedimentation followed by density gradient centrifugation on metrizoate polysucrose (Lymphoprep ${ }^{\circledR}$, Nyegaard, Oslo, Norway) as described by Böyum. ${ }^{18}$ Mononuclear cells were washed twice in Eagle's minimal essential medium (MEM; Difco) and adjusted to $1 \times 10^{6}$ monocytes per $\mathrm{ml}$ in MEM with $2 \%$ human serum albumin. The percentage of monocytes on cytocentrifuge preparations was in the range $18 \%-24 \%$ as assessed by morphology on Wright's stain and cytochemical identification of non-specific esterase. ${ }^{19}$ Polymorphonuclear leucocytes were washed twice in Gey's solution, remaining erythrocytes removed by hypotonic lysis, and cells adjusted to $2 \times 10^{7}$ per $\mathrm{ml}$ in Gey's solution with $1 \%$ human serum albumin. The purity of polymorphonuclear leucocytes was always $>95 \%$.

\section{CHEMOTAXIS}

The chemotactic response was determined in modified, reversible Boyden chambers as previously described. ${ }^{20}$ Polymorphonuclear leucocytes chemotaxis was performed in triplicate by placing $0.5 \mathrm{ml}$ of the cell suspension in the upper compartment of the Boyden chamber separated from the lower compartment by a nitrocellulose filter with a pore size of $3 \mu \mathrm{m}$ (Sartorius, Germany). The lower compartment was filled with $0.5 \mathrm{ml}$ of the appropriate dilutions of $H$ pylori sonicate or a known cytotaxin as indicated below. In each experiment the spontaneous migration towards medium was assessed

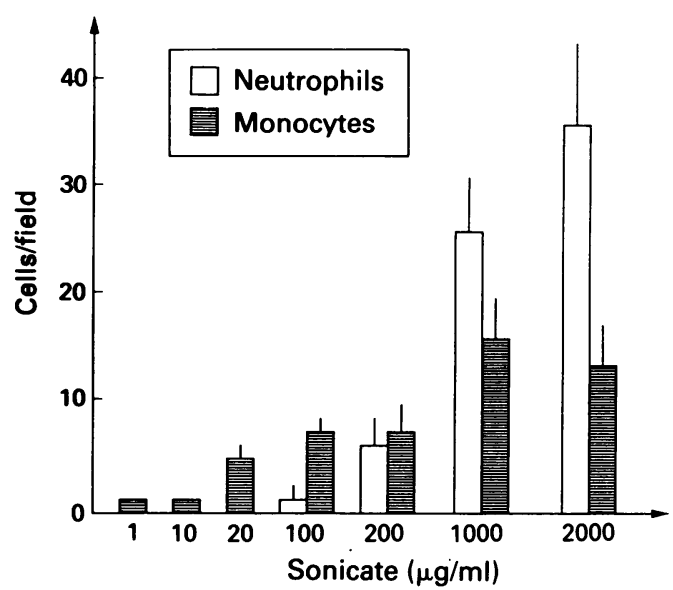

Figure 1: Migration of human polymorphonuclear leucocytes and monocytes towards various concentrations of a

Helicobacter pylori sonicate. Results represent the mean (SEM) of three experiments performed in triplicate with polymorphonuclear leucocytes and in duplicate with monocytes. Results are expressed as number of cells per high power field in chambers with sonicate minus number of cells per high power field in chambers with medium.

as a negative control. The chambers were incubated at $37^{\circ} \mathrm{C}$ for 150 minutes, after which the filters were fixed in ethanol, stained with haematoxylin and mounted on slides. The cells which had migrated completely through the filter were counted by direct microscopy in five fields on each filter, and the results expressed as number of polymorphonuclear leucocytes per field.

Monocyte chemotaxis was assessed in duplicate and with polycarbonate filters with a pore size of $5 \mu \mathrm{m}$ (Nuclepore, Pleasanton, Ca, USA). The chambers were incubated in 90 minutes at $37^{\circ} \mathrm{C}$ and the monocytes that had migrated completely through the filter were counted in $\mathbf{1 0}$ random fields in each filter. The results are expressed as the number of monocytes per field.

\section{CYTOTAXINS}

The following agents were used: (i) N-fmethionyl-leucyl-phenylalanine $10^{-8} \mathrm{M}$ (fMLP; Sigma Chemical Co, St Louis, Mo, USA), (ii) $5 \%$ zymosan-activated serum (ZAS) prepared as described, ${ }^{20}$ (iii) Pseudomonas aeruginosa sonicate prepared from a patient isolate, ${ }^{22}$ and (iv) $1 \%$ casein (Merck, Germany). All reagents were diluted in Gey's solution or Eagles minimal essential medium at their optimal chemotactic concentration and adjusted to $\mathrm{pH} 7 \cdot 2$ for polymorphonuclear leucocyte assays and $\mathrm{pH} 7 \cdot 0$ for monocyte assays.

TABLE I Comparison of human polymorphonuclear leucocyte and monocyte chemotaxis towards $\mathrm{H}$ pylori sonicate and four other cytotaxins: $1 \%$ casein, $5 \%$ zymosan-activated serum (ZAS), N-f-methionyl-leucyl-phenylalanine ( $F M L P)$, and Pseudomonas aeruginosa sonicate $750 \mathrm{\mu g} / \mathrm{ml}$

\begin{tabular}{lcl}
\hline Cytotaxin & $P M N s$ & Monocytes \\
\hline H pylori $4000 \mu \mathrm{g} / \mathrm{ml}$ & $112(8)$ & $15(4)$ \\
H pylori $2000 \mu \mathrm{g} / \mathrm{ml}$ & $36(3)$ & $12(3)$ \\
Paeruginosa $750 \mu \mathrm{g} / \mathrm{ml}$ & $165(14)$ & $21(4)$ \\
ZAS $5 \%$ & ND & $23(3)$ \\
Casein $1 \%$ & ND & $20(2)$ \\
fMLP $10^{-8} \mathrm{M}$ & $181(21)$ & $16(3)$
\end{tabular}

Results represent the number of cells per high power field,

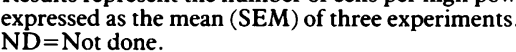


TABLE II Effect of heat treatment of $\mathrm{H}$ pylori sonicate on chemotactic activity against human polymorphonuclear leucocytes and monocytes. All experiments performed with protein concentration $1000 \mathrm{\mu g} / \mathrm{m}$

\begin{tabular}{lcc}
\hline Treatment & $P M N s / n]$ & Monocytes $[n]$ \\
\hline Untreated & $63(15)[5]$ & $12 \cdot 2(3 \cdot 7)[11]$ \\
$56^{\circ} \mathrm{C} 15^{\prime}$ & $55(22)[3]$ & $15 \cdot 6(3 \cdot 4)[3]$ \\
$70^{\circ} \mathrm{C} 15^{\prime}$ & $60(13)[3]$ & $16 \cdot 1(2 \cdot 5)[5]$ \\
$100^{\circ} \mathrm{C} 15^{\prime}$ & $71(17)[5]$ & $10 \cdot 6(3 \cdot 0)[11]$ \\
$100^{\circ} \mathrm{C} 60^{\prime}$ & Not done & $10 \cdot 8(3 \cdot 1)[4]$ \\
$100^{\circ} \mathrm{C} 15^{\prime}+$ dialysis & $3(1)[3]$ & $0 \cdot 9(0 \cdot 2)[3]$ \\
\hline
\end{tabular}

Results represent the number of cells per high power field, expressed as the mean (SEM) migrating towards sonicate afte subtracting spontaneous migration towards medium.

\section{Results}

The crude sonicate preparation of Helicobacter pylori exhibited a concentration dependent chemotactic activity towards human polymorphonuclear leucocytes and blood monocytes (Fig 1). Below $100 \mu \mathrm{g} / \mathrm{ml}$ no activity with polymorphonuclear leucocytes was observed, whereas monocytes migrated towards sonicate concéntrations at $1 \mu \mathrm{g} / \mathrm{ml}$, although with weak activity. Peak activity with monocytes was observed at concentrations of $1000-8000 \mu \mathrm{g} / \mathrm{ml}$ and with polymorphonuclear leucocytes $8000 \mu \mathrm{g} / \mathrm{ml}$ gave a peak chemotactic response of the same magnitude as with optimal fMLP concentration $\left(10^{-8}\right.$ $M)$. The chemotactic activity was similar in preparations before and after high speed centrifugation of sonicate (data not shown), and the activity was not different in preparations sonicated three or five times for 45 seconds (data not shown). The chemotactic response elicited by $H$ pylori sonicate was compared with the optimal response to previously described cytotaxins (Table I). The response to $4000 \mu \mathrm{g} / \mathrm{ml}$ was $62 \%$ for polymorphonuclear leucocytes and $93 \%$ for monocytes when compared with the response to fMPL. In additional control experiments, sonicate preparations of two unrelated clinical isolates gave comparable chemotactic activity (data not shown)

Further experiments were undertaken to partially characterise the chemoattractant nature of the crude sonicate. Dialysis overnight with a cut off at 6-8 kDa did not reduce the chemotactic activity for polymorphonuclear leucocytes or monocytes (data not shown). Preincubation of the sonicate at $1000 \mu \mathrm{g} / \mathrm{ml}$ with proteinase completely destroyed activity ( 0 cells/field $v 18$ (3) cells/field in untreated sonicate), whereas sonicate incubated with preboiled proteinase had a slightly lower activity towards monocytes (15 (3) cells/field). Proteinase $2 \mathrm{mg} / \mathrm{ml}$ itself had no chemotactic activity.

Heat treatment of Helicobacter pylori sonicate did not reduce the chemotactic activity and treatment for 15 minutes at $56^{\circ} \mathrm{C}$ or $70^{\circ} \mathrm{C}$ even increased the activity, but without statistical significance (Table II). The activity against monocytes after treatment for 15 minutes at $100^{\circ} \mathrm{C}$ was $87 \%$ of control $(n=11$; not statistically significant). Dialysis of the boiled sonicate completely removed the chemotactic activity for both polymorphonuclear leucocytes and monocytes, however, reflecting low molecular weight property of this activity.

Characterisation of the non-dialysable pro- teinous cytotaxin(s) of the crude sonicate was attempted by graded ammonium sulphate precipitations and molecular gel filtration. With increasing concentrations of ammonium sulphate most of the chemotactic activity for polymorphonuclear leucocytes was found in $10 \%$ precipitate, whereas activity for monocytes also was observed in $15 \%$ and $25 \%$ fractions (Table III). The chemotactic responsiveness of the phagocytes was assessed at suboptimal concentrations of bacterial protein thus allowing detection of the concentration of activity in single fractions - that is, in $10 \%$ ammonium sulphate. Dose response experiments of $10 \%$ ammonium sulphate precipitated sonicate revealed chemotactic activity for monocytes at $200,100,50,10$, and $1 \mu \mathrm{g} / \mathrm{ml}$, whereas the activity for polymorphonuclear leucocytes was undetectable below $200 \mu \mathrm{g} / \mathrm{ml}$. Molecular size chromatography of the $10 \%$ ammonium sulphate precipitation gave maximal chemotactic activity for monocytes in the fractions 10-15 corresponding to molecular weights between 25 and $35 \mathrm{kDa}$ as assessed by immunoblotting (Fig 2), although the activity was also seen outside this size range, but at a much lower level.

\section{Discussion}

The selective localisation of Helicobacter pylori to the gastric epithelium in patients with active chronic gastritis suggests an aetiological role of this microorganism in maintaining a chronic infection in the mucosal lesions. The cellular immunopathology of this interaction is largely unknown, but histopathological examinations of the mucosa show a high correlation of $H$ pylori with polymorphonuclear leucocyte and macrophage infiltration. ${ }^{112}$ The present study provides evidence that $H$ pylori contains chemotactic activity for human phagocytes, and this suggests an important role for this bacterial product(s) in attracting polymorphonuclear leucocytes to the site of infection. In addition, bacterial activation of complement factors may generate the cytotactic split product $\mathrm{C} 5 \mathrm{a},{ }^{17}$ but it is unclear if the gastric mucosal surface contains sufficient amounts of complement proteins to give this mechanism in vivo significance.

Several bacterial species have been reported to exhibit chemotactic activity for human phagocytes, but only few have been characterised. ${ }^{23-25}$ The cytotaxin(s) identified from our $H$ pylori

TABLE III Chemotactic activity of non-dialysable $\mathbf{H}$ pylori sonicate after precipitation with ammonium sulphate $(A S)$ of different concentrations. All experiments performed with protein concentration $200 \mu \mathrm{g} / \mathrm{ml}$

\begin{tabular}{lcc}
\hline Treatment & PMNs & Monocytes \\
\hline Untreated (AS) & $2(1)$ & $9(2)$ \\
$10 \%$ & $90(16)$ & $15(3)$ \\
$15 \%$ & $6(2)$ & $15(3)$ \\
$25 \%$ & $5(2)$ & $8(2)$ \\
$40 \%$ & $3(1)$ & $5(2)$ \\
$50 \%$ & $3(1)$ & $5(1)$ \\
$75 \%$ & $7(2)$ & $3(1)$ \\
$85 \%$ & $1(1)$ & $5(2)$ \\
$95 \%$ & $9(1)$ & $5(2)$ \\
\hline
\end{tabular}

The results are expressed as mean (SEM) number of cells per high The results are expressed as mean (SEM) number of cells per high power field of three experim
or duplicate (monocytes) 


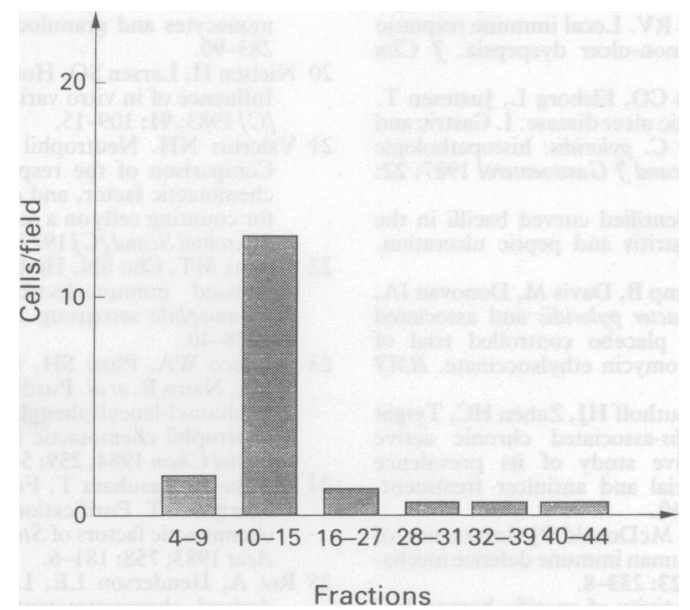

Figure 2: Gel filtration of dialysed and 10\% ammonium sulphate precipitated Helicobacter pylori sonicate on a Sephadex G-50 column. The figure shows chemoattractant activity towards monocytes tested in duplicate.

sonicates differs from previously reported bacterial cytotaxins in several ways. In contrast with the low molecular weight factors derived from Eschericia coli ${ }^{23}$ and Staphylococcus aureus, ${ }^{25}$ the present study has identified the activity from Helicobacter pylori to be non-dialysable and in the molecular range of 25 to $35 \mathrm{kDa}$. We conclude that $\mathrm{N}$-formyl oligopeptides are not the active cytotaxins in $H$ pylori preparations. The potency of the sonicate cytotaxin(s) was comparable with other bacterial derived factors, and blood monocytes were attracted at even lower concentrations than reported for Legionella pneumophila and Pseudomonas aeruginosa. ${ }^{26}$ It is at present unknown, if the cytotaxin(s) identified by us is similar to the recently reported $H$ pylori surface protein(s) with chemotactic activity for human monocytes, as the preliminary report by Mai et al ${ }^{27}$ did not characterise the chemical nature of the activity.

As the active component(s) was partially purified by ammonium sulphate precipitation and molecular gel filtration the relative activity increased reflecting selective removal of noncytotactic proteins. Eluted fractions were assayed at a minimum of two dilutions in order to avoid the possibility of depressed chemotactic responses that may occur at high concentrations of attractant. The chemotactic response of polymorphonuclear leucocytes and blood monocytes was uniformly observed with sonicates of three different clinical isolates of $H$ pylori, but further studies are needed to confirm if the production of a cytotaxin for human phagocytes is a general feature of this bacterial species.

As the activity was completely destroyed by proteinase incubation the chemical nature of the active component(s) probably is a polypeptide. It was, however, not abolished by heat treatment as might be expected of a protein. Further experiments of boiled sonicate revealed that all activity disappeared after dialysis suggesting the breakdown of a larger protein to smaller fragments retaining biological activity. The finding of increased cytotactic activity after heat treatment at $56^{\circ} \mathrm{C}$ and $70^{\circ} \mathrm{C}$ may be explained by changes of protein conformation so that active sites are exposed to a higher degree than in the native form.

The chemotactic responsiveness was established in polymorphonuclear leucocytes and blood monocytes probably reflecting a common reactivity of myeloid derived cells to the 25 to 35 $\mathrm{kDa}$ cytotaxin(s) in $10 \%$ ammonium sulphate precipitation preparations, although monocytes appears to respond weakly to additional molecules in other fractions. Preliminary experiments suggest that the influence of $H$ pylori sonicate on oxidative burst responsiveness involves both phagocytic cell types as well (Nielsen and Andersen, unpublished results). No information on the nature of the cellular interaction with the cytotaxin at the receptor level is yet available.

The immune response to $H$ pylori infection of the gastric mucosa includes a pronounced generation of IgG and IgA. ${ }^{710}$ In cases of chronic gastritis and relapsing ulcers it is clear that immunoglobulins are insufficient to erradicate the infection despite of the high antibody titres against $H$ pylori. Therefore, other immunological mechanisms are required to control the infection, of which the killing capacity of polymorphonuclear leucocytes and mononuclear phagocytes could be important. Killing of $H$ pylori by human phagocytes, however, requires a high proportion of phagocytes per bacteria (Andersen, Blom, and Nielsen; manuscript submitted), which makes this function ineffective in vivo as the bacteria generally exceed polymorphonuclear leucocytes in areas of active chronic gastritis. Release of reactive oxygen radicals or proteolytic enzymes from stimulated polymorphonuclear leucocytes may contribute to the chronicity and tissue damage characteristic of gastric inflammatory diseases, and the continued accumulation of phagocytes at the inflammatory site caused by the production of a cytotaxin by $H$ pylori could be an important pathogenic mechanism in this situation.

This study was supported by a grant from Danish Medical Research Council (No S12-9752). The expert technical assistance of Birgitte Sander Nielsen and Jette Moller Pedersen is appreciated. We thank Professor N Hoiby for Pseudomonas aeruginosa sonicate preparations.

1 Goodwin CS, Armstrong JA, Chilvers T, Peters M, Collin MD, Sly L, et al. Transfer of Campulobacter pylori and $\mathrm{MD}$, Sly $\mathrm{L}$, et al. Transfer of Campvlobacter pvlori and
Campylobacter mustelae to Helicobacter gen. nov. as Campylobacter mustelae to Helicobacter gen. nov. as
Helicobacter pvlori comb. nov. and Helicobacter mustelae comb. nov., respectively. Int F Syst Bacteriol 1989; 39: 397 405

2 Blaser MJ. Helicobacter pylori and the pathogenesis of gastroduodenal inflammation. F Infect Dis 1990; 161: 626-33.

3 Goodwin CS, Armstrong JA, Marshall BJ. Compvlobacter pyloridis, gastritis, and peptic ulceration. $\mathcal{F}$ Clin Pathol 1986 39: 353-65.

4 Marshall BJ. Campvlobacter pvloridis and gastritis. F Infect Dis 1986; 153: 650-7.

5 Drumm B, Sherman P, Cutz E, Karmali M. Association of Campylobacter pylori on the gastric mucosa with antral Campylobacter pylor on the gastric mucosa with an
gastritis in children. N Engl f Med 1987; 316: 1557-61.

6 Andersen LP, Holck S. Possible evidence of invasiveness of Helicobacter (Campylobacter) pulori. Eur f Clin Microbiol Helicobacter (Campylobacte

7 Drumm B, Perez-Perez GI, Blaser MJ, Sherman PM. Intrafamilial clustering of Helicobacter pvlori infection. $N$ Engl f Med 1990; 322: 359-63.

8 Marshall BJ, Armstrong JA, McGechie DB, Glancy RJ. Attempts to fulfil Koch's postulate for pyloric campylobacter. Med F A ustr 1985; 142: +36-9.

9 Dooley CP, Fitzgibbons PL, Cohen H, Appleman MD, Pere\% Pere\% GI, Blaser MJ. Prevalence of Campylobacter pylor infection and histologic gastritis in asymptomatic person -correlation with gastritis and duodenal inflammation. NEnglf Med 1989; 321: 1562-6. 
10 Wyatt JI, Rathbone BJ, Heatley RV. Local immune response to gastric Campylobacter in non-ulcer dyspepsia. F Clin 863-70.

11 Andersen LP, Holck S, Povlsen CO, Elsborg L, Justesen T Campylobacter pyloridis in peptic ulcer disease. I. Gastric and duodenal infection caused by $C$. pyloridis: histopathologic and microbiologic findings. Scand $\mathscr{f}$ Gastroenterol 1987; 22 219-24.

12 Marshall BJ, Warren JR. Unidentified curved bacilli in the stomach of patients with gastritis and peptic ulceration. Lancet 1984; i: 1311-5.

13 McNulty CAM, Gearty JC, Crump B, Davis M, Donovan IA Melikian V, et al Campylobacter pyloridis and associated gastritis: investigator blind, placebo controlled trial of bismuth salicylate and erythromycin ethylsuccinate. $B M \mathcal{F}$ 1986; 293: 645-9.

14 Rauws EAJ, Langenberg W, Houthoff HJ, Zanen HC, Tytgat GNJ. Campylobacter pyloridis-associated chronic active antral gastritis. A prospective study of its prevalence and the effects of antibacterial and antiulcer treatment. Gastroenterology 1988; 94: 33-40.

15 Pruul H, Lee PC, Goodwin CS, McDonald PJ. Interaction of Campylobacter pyloridis with human immune defence mechanisms. F Med Microbiol 1987; 23: 233-8.

16 Tosi MF, Crinn SJ. Opsonic activity of specific human IgG against Helicobacter pylori. F Infect Dis 1990; 162: 156-62.

17 Bertowska E, Jose O, Davies H, Stephenson M, Webster D Interaction of campylobacter species with antibody, complement and phagocytes. Gut 1989; 30: 906-11.

18 Böyum A. Isolation of mononuclear cells and granulocytes from human blood. Scand F Clin Lab Invest 1968; 21 (supp from human

19 Yam LT, Li CY, Crosby WH. Cytochemical identification of monocytes and granulocytes. Am ifm Pathol 1971; 55: 283-90

20 Nielsen H, Larsen SO. Human monocvte chemotaxis in vitro. Influence of in vitro variables. Acta Pathol Microbiol Scand [C] 1983; 91: 109-15.

21 Valerius NH. Neutrophil granulocyte chemotaxis in vitro. Comparison of the response to casein and to a bacterial chemotactic factor, and evaluation of an automatic method for counting cells on a membrane filter surface. Acta Pathol Microbiol Siand /C J 1977; 85: 289-96.

22 Collins MT, Cho SN, Hoiby N, Espersen F, Bak L, Reif JS Crossed immunoelectrophoretic analysis of Leegionella pneumophila serogroup 1 antigens. Infect Immun 1983; 39 $1428-40$.

23 Marasco WA, Phan SH, Krutzsch H, Showell HJ, Feltner DE, Nairn R, et al. Purification and identification of formyl methionvl-leucvl-phenvlalanine as the major peptide methion neutrophil chemotactic factor pro

24 Mivake Y, Yasuhara T, Fukui K, Suginaka H, Nakajima T, Morivama T. Purification and characterisation of neutrophil chemotactic factors of Streptococcus sanguis. Biochim Biophys Acta 1983; 758: 181-6.

25 Rot A, Henderson I.E, I.eonard EJ. Staphylococius aure'us derived chemoattractant activity for human monocites F Leukoc Biol 1986; 40: +3-53.

26 Rechnitzer C, Kharazmi A, Nielsen H. Effects of Legiomella pneumophila sonicate on human neutrophil granulocyte and 27 mai UEH chemotaxis. Eur f Clin Invest 1986; 16: 368-75. S UEH, Pere\%-Pere\% GI, Wahl L.M, Wahl S.M, Blaser.MJ Smith PI). Soluble surface proteins from Helicobacter pylor activate monocytes/macrophages by lipopolysactharide independent mechanism. F (.lin Ineest 1991; 87: 89+-900. 